\title{
Assessing recycled/secondary materials as pavement bases
}

S. Saride PhD, A. J. Puppala PhD and R. Williammee BSCE

The use of recycled or secondary materials in pavement construction is gaining popularity owing to the added advantages over conventional materials, which include the conservation of natural resources, conservation of energy, preservation of the environment and reduction in life-cycle costs. In this research, two types of recycled materials, namely reclaimed asphalt pavement and cement-stabilised quarry fines, were utilised as pavement base materials for a highway extension project in Arlington, Texas, USA. Prior to the construction of test sections, a series of laboratory studies including strength, compressibility, swell/shrink and resilient modulus tests were performed on the selected base materials to verify their suitability as base materials for pavement construction. Pavement test sections were instrumented with horizontal inclinometers and pressure cells to monitor the long-term performance of these new base materials. Pavement surface profiling surveys were also conducted at regular intervals to monitor for any accumulated roughness of the pavement surfaces. Analysis of results obtained from both laboratory and field monitoring studies demonstrates that these secondary materials can be effectively used as pavement bases. The sustainability issues of this project are also discussed in detail.

\section{INTRODUCTION}

In the United States, the total recycling process stream is estimated to be around $800 \mathrm{Mt}$ per annum. The recent studies by the waste and resources action programme (WRAP) estimates that construction, demolition and excavation waste production alone accounts for $120 \mathrm{Mt}$ per annum in the UK. This programme also estimates that at least $20 \%$ of the unused waste is going to landfill every year. If not reused properly, all these recycled or secondary materials will be stockpiled near the sources of production or deposited in landfills and this leads to environmental disposal problems.

In the USA, more than $50 \mathrm{Mt}$ of asphalt paving material are milled annually (Taha et al., 1999). The recycled materials market, comprised of reclaimed asphalt pavements, lightweight aggregates, fly ash, and quarry by-products, is estimated to be between 352 and 859 Mt per year. Collins and Ciesielski (1994) reported that the annual production of quarry by-products alone amounts to $175 \mathrm{Mt}$ and these by-products are used in many geotechnical applications such as flowable fills and embankment fills.

In the UK, at least $41 \mathrm{Mt}$ of quarry by-products are produced annually (Manning, 2004). The construction and demolition waste alone deposited every year in landfills is around $70 \mathrm{Mt}$, of which around 15\% of the recycled/secondary materials is being used by the highway agencies in road construction (Lambert et al., 2006).

Recycled pavement materials have become a viable alternative for consideration in road construction. Conservation of natural resources, preservation of the environment, and retention of existing highway geometrics are some of the benefits obtained by reusing pavement materials (Taha et al., 1999). Utilisation of alternative materials in the place of conventional materials, recycling, and energy efficiencies are main applications of sustainability in geotechnical engineering (Abreu et al., 2008). They also mitigate environmental impacts (reduced need for natural aggregates, no land filling of demolition waste) and reduce the use of oil-based hydrocarbon binders.

Reid and Chandler (2001) summarised the production rates, availability of alternative materials and their potential use in pavement construction applications in the UK. Ellis (2003) also highlighted the importance of recycling in the transportation industry in the UK. Chesner et al. (2001) produced a list of byproducts that have significant application in road construction in the USA. To increase these recycling efforts and to address sustainability in the pavement construction sector, it is extremely crucial to identify potential recycled/secondary materials and investigate their promising applications in civil engineering construction.

To improve the sustainability, design procedures should be developed based upon the performance of available materials instead of demanding the use of a standard material. However, the recycled/secondary materials reclaimed from standard materials may have several issues related to either environmental effects or socio-economic concerns and therefore, before adopting these recycled/secondary materials for any construction project, any such issues must be addressed through simple sustainability indicators (Jefferis, 2008; Jefferson et al., 2007). The main indicator for sustainable geotechnical work is an awareness of the amount of waste generated in civil engineering works. Another tool such as life- 
cycle assessment is helpful in the material and processes selection phase at the design office, whereas different indicators are needed for use on site.

Nunes et al. (1996) summarised the environmental aspects of using these recycled materials in pavement construction. Alkins et al. (2008) highlighted that the adoption of cold in-place recycling of existing pavements can reduce construction-related greenhouse gas emissions to the extent of around 50\% when compared with conventional pavement rehabilitation techniques such as milling and asphalt overlay of distressed pavements.

In the present study, the application of two types of recycled/ secondary materials, namely reclaimed asphalt pavement (RAP) and quarry fines $(\mathrm{QF})$ for use as roadway base materials for a highway construction project by the Texas Department of Transportation (TxDOT), was investigated because a successful application would promote sustainable development in the pavement industry. The project site location details are shown in Figure 1. The following section presents more insights into the selected recycled/secondary materials.

\section{BACKGROUND}

Generally, the existing hot-mix asphalt (HMA) materials are milled and screened to produce pieces with a maximum halfinch $(12.7 \mathrm{~mm})$ size for batch plants or a maximum quarterinch $(6.35 \mathrm{~mm})$ size for continuous feed plants. The milled materials are usually fed into the middle of a dryer or drummixer and mixed with the natural aggregates before adding the virgin asphalt binder. Specifically, the main advantage of using RAP aggregates in place of local soils is to increase the strength and modulus and minimise the potential vertical rise (PVR) due to swelling or shrinkage of clay soil.
New Hampshire Department of Transportation (NHDOT) studied the potential use of reclaimed asphalt pavement as a base material in a full-scale field experiment (Janoo, 1994). Test sections of different RAP materials were built by the NHDOT near Concord on Interstate Highway 89 with the objective of determining the layer coefficients to use in the pavement design. Heavyweight deflectometer, dynamic cone penetrometer and field California bearing ratio tests were conducted on the test sections to obtain the deflections. The deflections were used to back-calculate the layer moduli, which were then used in the established relationships for determining the layer coefficients from the 1993 AASHTO Guide for Design of Pavement Structures (AASHTO, 1993).

In another study conducted by Taha et al. (2002), RAP and virgin aggregate mixtures were tested with different cement dosages. Compaction and unconfined compressive strength (UCS) tests were conducted in the study. The modulus values were determined from the UCS results using correlations between resilient modulus $\left(\boldsymbol{M}_{R}\right)$ and the UCS properties. No resilient modulus tests were conducted in the laboratory. The layer coefficient charts included in the AASHTO Guide for Design of Pavement Structures (AASHTO, 1993) were used in obtaining the values. Tao et al. (2008) studied different recycled materials including RAP and ground granulated blastfurnace slag (ggbfs) as pavement bases in full-scale accelerated pavement testing sections and reported that the ground ggbs stabilised with blended calcium sulfate provided a cost-effective alternative to conventional pavement base materials. Puppala et al. (2009) performed a series of resilient modulus tests on cement (type I/II) and cement-fibre-treated RAP for use as pavement base material. They reported that the structural coefficient values increased with an increase in the

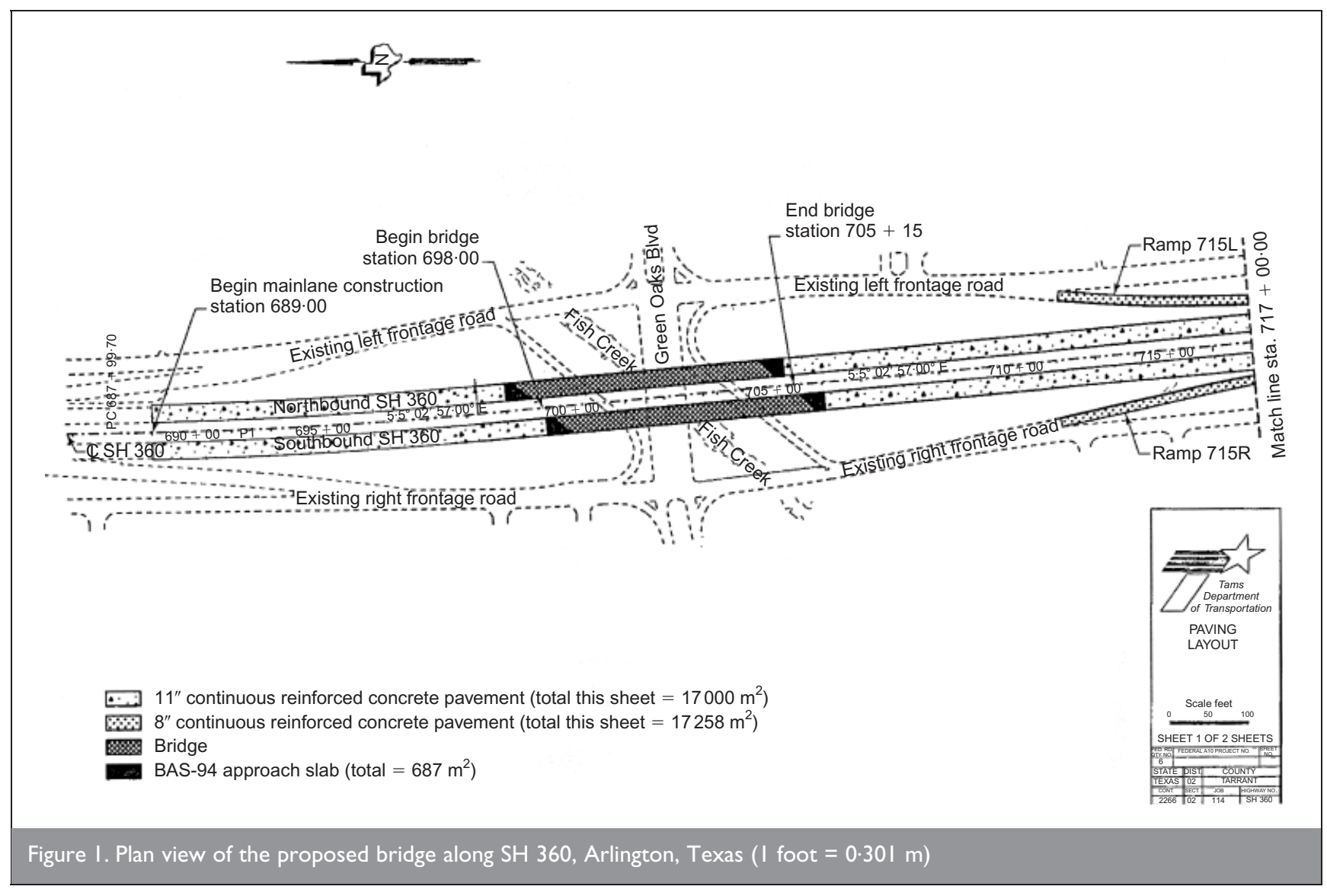


confining pressure and these values were higher for cement and cement-fibre-treated aggregates in comparison with untreated RAP. The significant increase of structural coefficients with cement-fibre treatment (30\%) was attributed to the tensile strength and interlocking properties offered by the fibre content.

Limestone quarry fines are a by-product from crushed natural stone produced for use as construction aggregate. The process consists of blasting, primary and secondary crushing, washing, screening and stockpiling operations. Quarry by-products are produced during crushing and washing operations (Tepordei, 1992). Quarry fines are generally angular and fine materials (Okamura, 1997). Depending upon the gradation, larger sizes can be used in concrete mixtures as fine aggregate (sand) to occupy a large volume and also in lateritic soil to improve its properties (Soosan et al., 2001). Replacement of sand with quarry fines can be considered an economical high-volume use option (Naik and Kumar, 2003). The application of recycled quarry fines, when substituted as natural sand, reduces the requirement for expensive chemical admixtures, high-range water-reducing admixtures (HRWRA) and viscosity-modifying admixtures (VMA) without affecting the strength of selfcompacting concrete and has been proved to be an economical solution for concrete producers (Tarun et al., 2005).

A survey conducted in 1994 showed that six states in the USA have used quarry waste material in pavement applications (Collins and Ciesielski, 1994). The research study conducted by Kumar and Hudson (1993) showed potential uses of quarry byproducts in cement-treated sub-base/flowable fill, mineral filler in HMA and as a slurry seal aggregate. Another study by Lee and Nicholson (1997) found that combining 10\% quarry tailings with a mixture of municipal solid waste ash would provide an effective landfill cover material.

Huffman (2001) reported on the acute disposal problems of the SRM Tarrant limestone quarry in Alabama due to its landlocked situation in the metropolitan area. His research showed promising applications of pond fines as soil caps or infiltration layers at local landfills. The engineering behaviour of pond fines was also found to be superior to local soils used for general fill. Fraser and McBride (2002) presented a study of the case-specific geotechnical properties of quarry fines when used as embankment material in a limestone quarry.

A review of the literature reveals that limited information is available on these recycled materials and hence there is a need for research to evaluate these secondary materials for their suitability in pavement sections. In this research, both laboratory and field studies were undertaken to evaluate the secondary materials as pavement bases in order to develop a sustainable pavement design definition.

\section{INVESTIGATIONS ON RECYCLED AND STABILISED MATERIALS}

\section{I. Laboratory tests}

3.1.1. Materials. Prior to construction of the pavement sections for the proposed State Highway 360 (SH 360) extension project at Green Oaks Boulevard in South Arlington,
Texas (Figure 1), a detailed geotechnical investigation was carried out on the proposed site. Three sample borings were drilled along the median of the roadway to a depth of around $6 \mathrm{~m}$. Undisturbed samples were collected from various depths to test for their suitability as a pavement subgrade soil. Limestone QF was obtained from a source in Oklahoma State, USA. The material was supplied at no cost but the department had to pay for the hauling charges for about $250 \mathrm{~km}$. RAP aggregates were obtained from the nearest stockpile. These recycled/secondary materials were also tested and analysed for their suitability as pavement base materials.

3.1.2. Methods. A series of laboratory tests were performed on the natural subgrade soil samples which includes Atterberg limits test, soluble sulfate content test, vertical free swell test, PVR test and compressibility tests to verify the suitability of the subgrade soil for pavement construction. The recycled/ secondary materials were subjected to classification and engineering tests to understand the strength, compressibility and resilient behaviour of these recycled materials. These tests included the UCS test, vertical free swell test, one-dimensional consolidation test and the resilient modulus test.

The Atterberg limits test was performed in accordance with the ASTM D4318 procedure (ASTM, 2005). The vertical free swell tests were conducted according to the procedure stipulated in ASTM D4546 (ASTM, 2008). One-dimensional consolidation tests were performed according to the ASTM D2435 procedure (ASTM, 2004). The UCS tests were conducted according to ASTM D2166 (ASTM, 2006) on cylindrical specimens of diameter $71 \mathrm{~mm}$ and length $142 \mathrm{~mm}$. The test procedure stipulated in AASHTO T 307-99 (AASHTO, 2003) was used to perform resilient modulus tests in a repeated load triaxial test apparatus. In all the engineering tests, triplicate samples were tested and the average results are reported.

The PVR tests were performed based on the test procedure, TEX-124-E, developed and standardised by the TxDOT (1999). The PVR of a soil is defined as the ability of a soil to swell when subjected to moisture fluctuations at given moisture content, density and loading conditions. In this procedure, the natural moisture content and the wet densities of each swelling soil layers are first determined from the core samples collected. The liquid limit (LL) and plasticity index (PI) of each swelling layers were also used in this analysis to calculate the minimum (dry) and maximum possible moisture (wet) conditions in the respective soil layers. These moisture contents can be obtained by using the following empirical relations

'Dry' moisture condition $=0 \cdot 2 \times \mathrm{LL}+9$

'Wet' moisture condition $=0.47 \times \mathrm{LL}+2$

The percentage volumetric change (under given loading condition) can now be read from the given chart between the moisture condition of the soil layer and PI of the soil layer. Then the percentage free swell (swell under no load condition) is calculated using the following formula 
Now, the PVR can be read from a graph of PVR values and load acting on each layer plotted against different percentage free swell values. The PVR values can be obtained at the top and bottom of each layer. The difference between these two values will give the actual PVR for that layer. Finally, the total PVR is calculated by taking the cumulative value of the individual contributing layers.

\subsubsection{Results and analysis. The laboratory test results are} summarised in Table 1 . These results indicate that subgrade soils are highly plastic in nature with a high potential to swell. No significant sulfates were found in the subgrade soils. The swelling potentials of the lime/cement-stabilised soils will increase due to the formation of a swelling mineral (ettringite), if the sulfate content is greater than 2000 ppm (Puppala et al., 2004).

As the QF exhibit low strength and resilient modulus properties due to the inert nature of the material, cement stabilisation of QF was considered. To enhance these material properties, 2.3\% of type I/II cement was added to the quarry fines and the stabilised material was used as a pavement base material. The optimum cement stabiliser was determined based on the targeted UCS strength of $1035 \mathrm{kPa}(150 \mathrm{psi})$ at 7 days curing period. Important tests were repeated on cemented quarry fine (CQF) specimens. Table 1 summarises the results of all tests performed on both recycled materials.

Test results indicate that the recycled materials were nonswelling natured, coarse-grained materials. The grain size distribution curves of the QF and RAP are shown in Figure 2. According to the Unified Soil Classification System (USCS), the QF and RAP materials were classified as silty sand (SM) and poorly graded sand (SP), respectively. The compaction characteristics (optimum moisture content and dry unit weight) of the QF were improved by stabilising with 2.3\% type I/II cement. The QF and RAP had very low compression index $\left(C_{\mathrm{c}}\right)$ values in comparison with the natural subgrade soils (Table 1) which reveals that the present recycled materials were of very low compressibility. The UCS tests were conducted in accordance with the ASTM D2166 and the results are presented in Table 1. A twelve-fold increase in compressive strength was observed with the cement treatment of QF. The high strength of the $\mathrm{CQF}$ is attributed to the cementing reactions between the cement and the fine sandy fraction of the QF material. The UCS of the RAP material was found to be $340 \mathrm{kPa}$. Among these

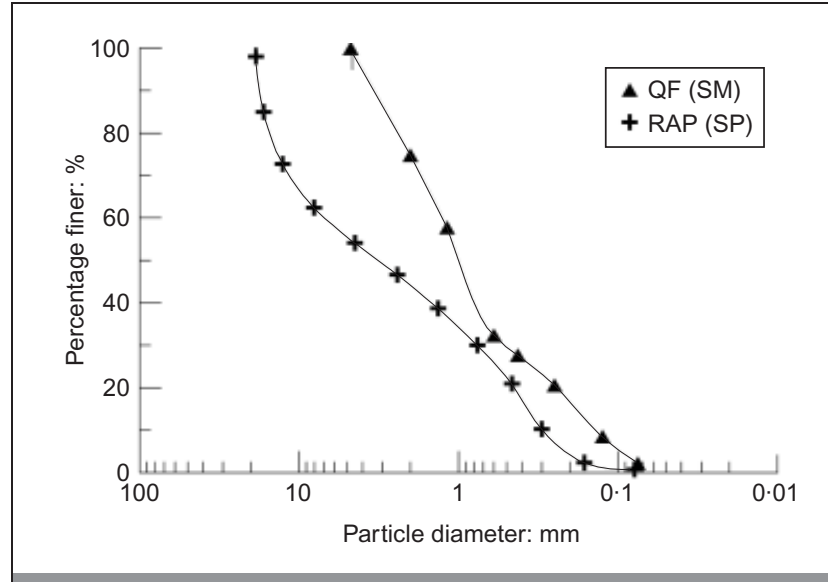

Figure 2. Grain size distribution curves of secondary materials

two secondary/recycled materials, the CQF showed higher strength characteristics due to the development of the cementitious bonds from cement treatment.

The resilient behaviour of these materials was studied using a cyclic triaxial test set-up as stipulated by the American Association of State Highway and Transportation Officials (AASHTO, 1993). Table 2 presents the results of resilient modulus tests carried out on both the untreated and treated recycled QF material. As expected, the cemented QF exhibited higher moduli than the untreated QF specimens. In addition, the resilient modulus of the QF and CQF increased with the confining stress. This trend suggests that the cemented granular material behaved as a strain-hardening material and the $\boldsymbol{M}_{R}$ properties depended on the confining pressure conditions. Figure 3 depicts the maximum resilient moduli values of the $\mathrm{QF}, \mathrm{CQF}$ and RAP with the confining pressure. The RAP exhibited higher moduli at low confining pressures in comparison with the CQF. The higher moduli for the RAP at low confining pressures were attributed to the angularity of the RAP material. At higher confining pressures, the CQF showed higher resilient modulus values. Overall, the strength and resilient behaviour of these materials reveal that these secondary materials were strong enough to withstand the pavement and traffic loads.

\subsection{Construction of test sections}

As the existing subgrade soils are highly expansive in nature, a combined lime-stabilised subgrade overlain by a base material (CQF and RAP) was designed to limit the total allowable PVR to $25 \mathrm{~mm}$ (1 in.) of the pavement surface during the life of the structure. RAP was used as the base course in the southbound SH360 direction whereas CQF was used as the base course in

\begin{tabular}{|c|c|c|c|c|c|c|c|c|}
\hline \multirow[t]{2}{*}{ Material } & \multirow{2}{*}{$\begin{array}{l}\text { Soil classification } \\
\text { (USCS) }\end{array}$} & \multirow[t]{2}{*}{ LL: \%; PI } & \multicolumn{2}{|c|}{ Compaction } & \multirow{2}{*}{$\begin{array}{l}\text { Compression } \\
\text { index, } C_{c}\end{array}$} & \multirow{2}{*}{$\begin{array}{l}\text { Free swell } \\
\text { strain: \% }\end{array}$} & \multirow[t]{2}{*}{ PVR: mm } & \multirow[t]{2}{*}{ UCS: $\mathrm{kN} / \mathrm{m}^{2}$} \\
\hline & & & OMC: \% & MD: $\mathrm{kN} / \mathrm{m}^{3}$ & & & & \\
\hline Subgrade & $\mathrm{CH}$ & $54 ; 40$ & - & - & 0.33 & 14.6 & 73 & - \\
\hline QF/CQF & SM & $21.5 ; 9.8 /-$ & $11.2 / 13.8$ & $18.8 / 17.9$ & $0.098 /-$ & $6 / 0$ & - & $120 / 1440$ \\
\hline RAP & SP & - & 6 & $21 \cdot 3$ & 0.126 & 0.8 & - & 340 \\
\hline
\end{tabular}

OMC, optimum moisture content; MD, maximum dry unit weight 


\begin{tabular}{|c|c|c|c|}
\hline \multirow{2}{*}{$\begin{array}{l}\text { Confining pressure }\left(\sigma_{\mathrm{c}}\right) \text { : } \\
\mathrm{kPa}\end{array}$} & \multicolumn{3}{|c|}{ Resilient modulus $\left(\boldsymbol{M}_{\mathrm{R}}\right)$ : $\mathrm{MPa}$} \\
\hline & QF & CQF & RAP \\
\hline $20 \cdot 7$ & 65 & 152 & 211 \\
\hline $34 \cdot 5$ & 118 & 216 & 251 \\
\hline 68.9 & 228 & 317 & 280 \\
\hline 103.4 & 232 & 351 & 300 \\
\hline $137 \cdot 9$ & 230 & 369 & 320 \\
\hline
\end{tabular}

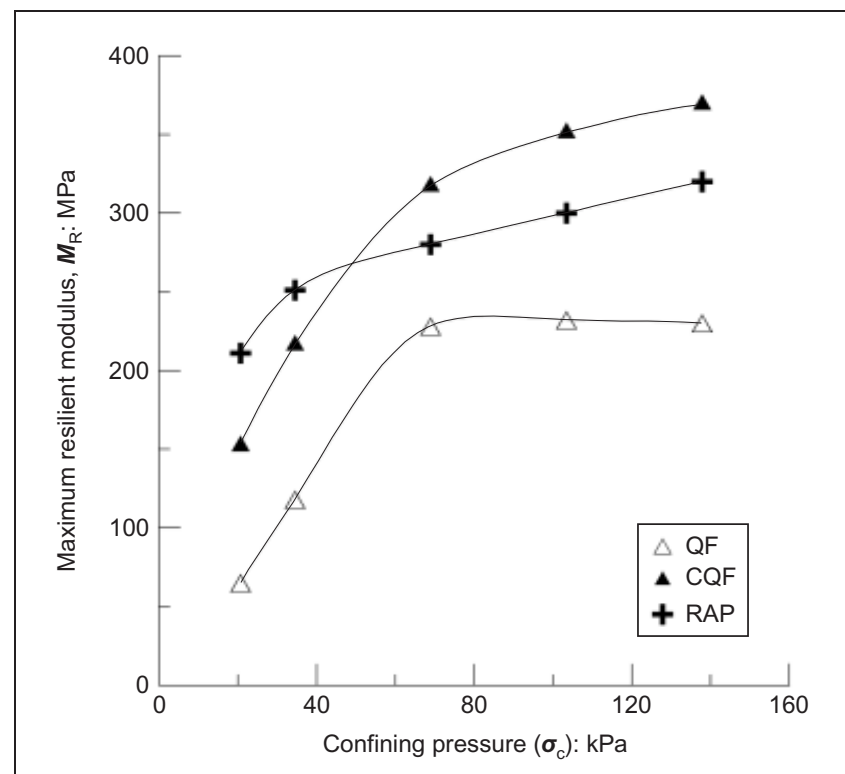

Figure 3. Variation of maximum resilient moduli with confining pressure

the northbound SH360 direction. Prior to the construction of the pavement layers, the subgrade was treated with 6\% lime. The lime dosage was determined according to the procedure outlined by Eades and Grim (1966). The stabilised subgrade layer thicknesses were designed on the basis of the resilient and strength behaviours of the selected secondary/recycled base materials. Figures 4 and 5 show the typical cross-sections of the south- and north-bound pavement sections, respectively.
The construction of the test sections was completed in the summer of 2006 and the highway was then opened to traffic immediately.

\subsection{Instrumentation and field monitoring studies}

3.3.1. Horizontal inclinometers. Horizontal inclinometers were installed prior to the placement of the continuously reinforced concrete pavement (CRCP) to monitor the surficial soil movements. The horizontal inclinometer system consisted of an inclinometer casing $0.08 \mathrm{~m}$ in diameter and a horizontal probe, control cable, pull cable, and a readout unit. The probes for the horizontal inclinometers consisted of one accelerometer which measured the tilt in the plane of the inclinometer wheels tracking along the internal longitudinal grooves of the casing. Another accelerometer measured tilt in the plane perpendicular to the wheels. Inclination measurements were converted to lateral deviations, which could be regarded as permanent deformations.

The horizontal inclinometer casings were installed to measure vertical displacements in the base and subgrade layers before these displacements grew large enough to be observed on the pavement surface in the form of excessive permanent deformation or cracking of the pavements induced by differential settlements. Large displacements necessitate engineering decisions on how to suppress future pavement surface roughness. The majority of the soil movements were expected to come from the compressions in untreated in situ soils, treated subgrade and base layers.

The inclinometers were of the closed end type with a pulley system and these were placed up to $16 \cdot 15 \mathrm{~m}$ in length across the main travel lanes. A long burrow, $0 \cdot 1 \mathrm{~m}$ wide and $0 \cdot 15 \mathrm{~m}$ deep, was excavated. The inclinometers were then placed $0.15 \mathrm{~m}$ below the top of the base layers. All the inclinometers were inclined at a downward slope angle of $5^{\circ}$ to facilitate any drainage from rainfall events. The trench was then filled with a flowable fill material. The installation of the horizontal inclinometers can be seen in Figure 6. The rest of the upper layers were replaced after the installation of the horizontal inclinometer.

Data collection was carried out twice a month as well as on the days following heavy rainfall events. Figure 7 presents the variation of cumulative vertical displacement with time for inclinometers placed in both the RAP and the CQF base layers. Initially, the displacements in the inclinometers were negligible. Noticeable displacements $(\sim 10 \mathrm{~mm})$ in both recycled materials were observed after 240 days (8 months) from the end of construction. Possible reasons for these displacements could be attributed to the heavy rainfall events in early 2007 


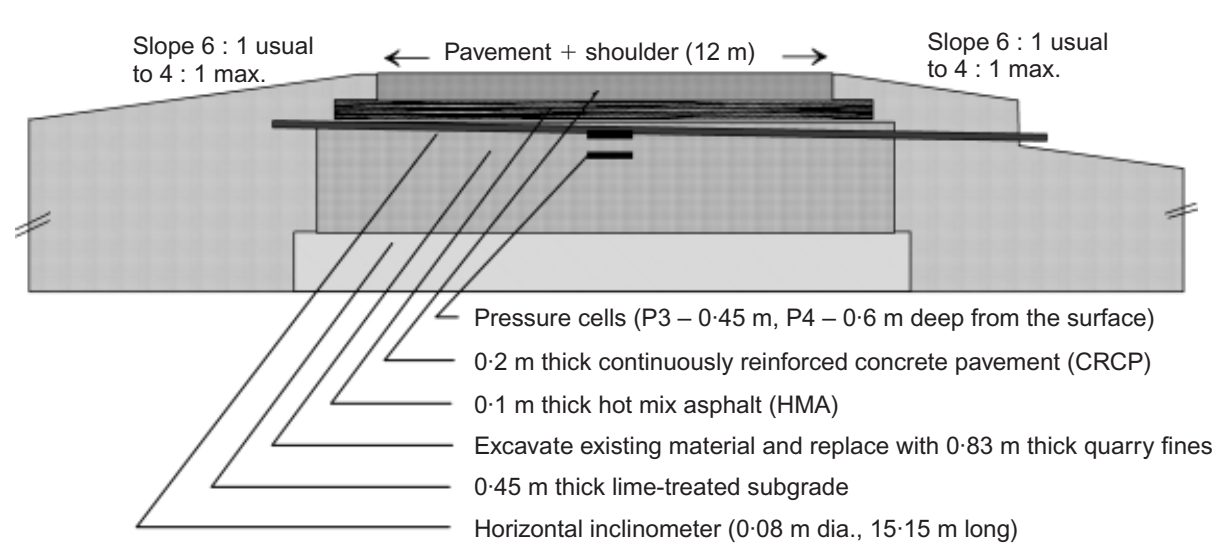

Figure 5. Typical northbound test embankment section with CQF as a base material SH 360, Arlington, Texas. Sta.715+00 to Sta. $737+00)$

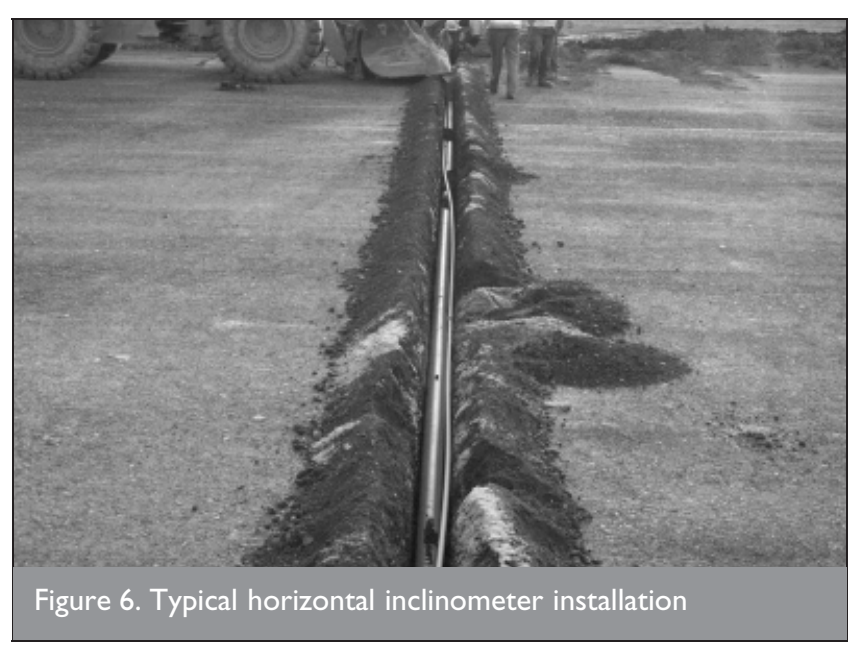

that might have induced soil movements of saturated soil layers under traffic loading.

The amount of rainfall recorded from the nearest weather station over this period is shown in Table 3, which indicates that an average monthly rainfall amount of $125 \mathrm{~mm}$ occurred at the test site in the first 6 months of 2007. Such high rainfall might have contributed to moisture-induced soil movements in the vertical direction. These movements $(10 \mathrm{~mm})$ were observed to be constant and were well within the permissible limit of $25 \mathrm{~mm}$. Any displacement beyond this threshold value requires pavement rehabilitation. Further monitoring of these test sections is necessary to assess the long-term performance of these recycled materials as an effective base material in the pavement systems.

\subsubsection{Pressure cells. Four pressure cells (P1, P2, P3 and P4)} were also installed underneath these two pavement test sections and their locations are also shown in Figures 4 and 5. These sensors measured the total pressures in the soils under traffic loads. These results were used to verify the design assumptions and assess the distribution of traffic-induced pressures to underlying soils. Pressure cells (P1 and P2) were placed in the RAP section on the southbound SH 360 at depths of 0.15 and $0.30 \mathrm{~m}$ below the top of the base layer, respectively. Pressure cells (P3 and $\mathrm{P} 4$ ) were placed in the CQF section along the northbound SH 360 at depths of $0 \cdot 15$ and $0 \cdot 3 \mathrm{~m}$, respectively. All pressure cells were placed inside the

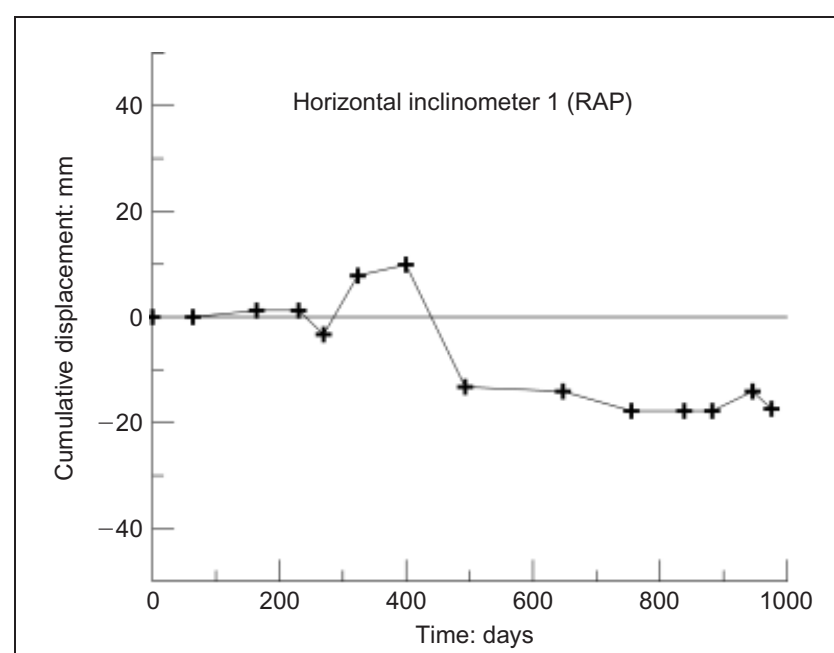

(a)

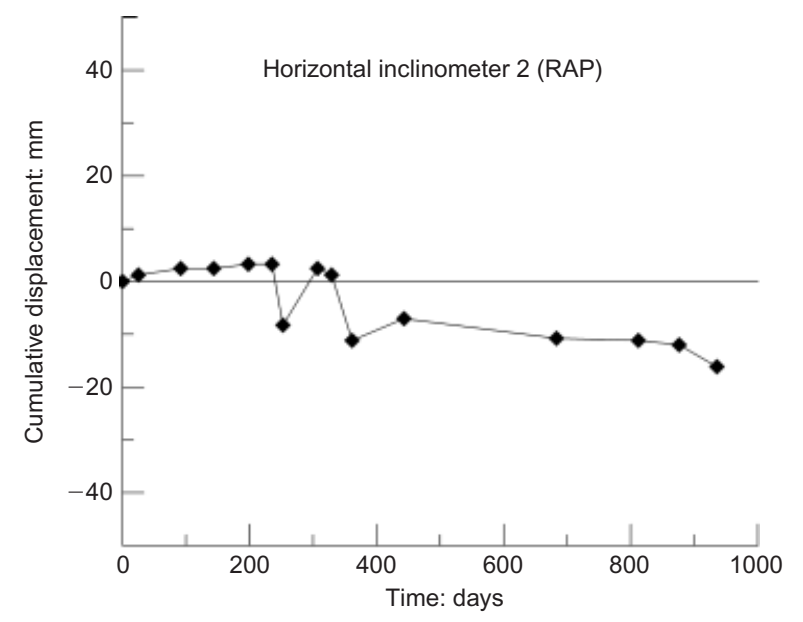

(b)

Figure 7. Cumulative vertical displacements of the horizontal inclinometers with time: (a) horizontal inclinometer in the RAP section; (b) horizontal inclinometer in the CQF section

travel lanes where the actual dynamic pressure response can be measured. The calibration factor for the pressure cells was $1 \mathrm{~mA}=43 \cdot 75 \mathrm{kPa}$.

The initial reading was taken before laying the HMA pavement. Sensor readings were taken once a month after the initial readings. Figure 8 shows the typical pressure data obtained 


\begin{tabular}{|lccl|}
\hline Month year & $\begin{array}{c}\text { Number of days } \\
\text { (from end of construction) }\end{array}$ & $\begin{array}{c}\text { Amount of } \\
\text { rainfall: } \mathrm{mm}\end{array}$ & Remarks \\
\hline May 2006 & 0 & 68 & Nominal rainfall period \\
June 2006 & 30 & 32 & \\
July 2006 & 60 & 14 & \\
August 2006 & 90 & 37 & \\
September 2006 & 120 & 57 & \\
October 2006 & 150 & 120 & \\
November 2006 & 180 & 46 & \\
December 2006 & 210 & 119 & Heavy rainfall period \\
January 2007 & 240 & 129 & \\
February 2007 & 270 & 21 & \\
March 2007 & 300 & 68 & \\
April 2007 & 330 & 257 & \\
May 2007 & 360 & 225 & \\
June 2007 & 390 & & \\
& & & \\
Table 3. Summary of rainfall data collected at the test site for the year 2006-2007 & & & \\
(Source: NOAA (2008)) & &
\end{tabular}

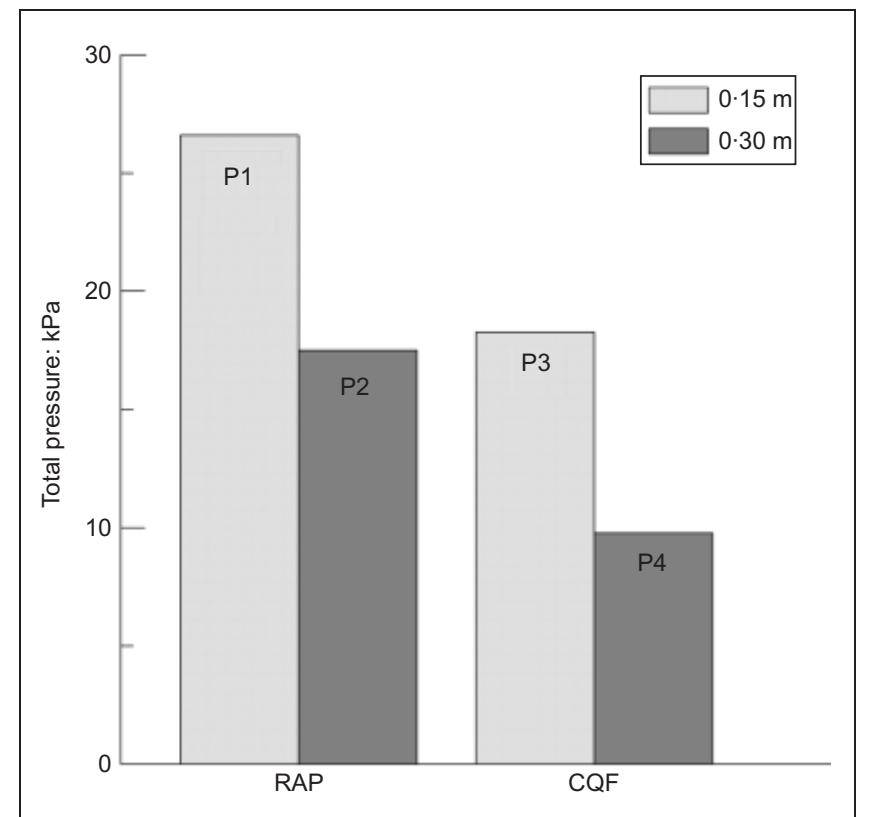

Figure 8. Typical pressures measured from the total pressure cells

from these pressure cells after correcting for the initial readings. As expected, higher pressures were recorded in the upper layers of the pavement bases in both RAP and CQF sections. With depth these pressures were diminished. Higher pressures were concentrated in the upper layers of RAP base $(27 \mathrm{kPa})$ in comparison with those in the CQF base $(17 \mathrm{kPa})$. These stress concentrations and variations could be attributed to the low moduli of the RAP materials when compared with the CQF materials. Furthermore, the thickness of the RAP base layer $(0.45 \mathrm{~m})$ was considerably smaller than that of the CQF base layer $(0 \cdot 83 \mathrm{~m})$.

Typically, the pressure exerted in a base layer by an $80 \mathrm{kN}$ single axle wheel load on a three-layer rigid pavement system (typical thickness of $0 \cdot 2 \mathrm{~m}$ ) built over a stabilised base layer has been reported to be around $35 \mathrm{kPa}$ (Sirivitmaitrie, 2008). For comparison, the pressures recorded in both the base layers of the present four-layer pavement system were around $20 \mathrm{kPa}$
(17-27 kPa) and these values were lower due to the incorporation of an additional HMA layer. Nevertheless, the results are comparable and this leads to the conclusion that both recycled base layers used in the present study performed in a similar manner to conventional base layers.

3.3.3. Pavement surface profiles. Surface profiling of both the pavement sections was carried out 2.5 years after construction of the test sections using a truck-mounted profiler. The profile data were analysed to obtain the international roughness index (IRI) to describe the riding quality. The IRI is defined as the accumulations of undulations of a given segment length of pavement and is usually reported in $\mathrm{m} / \mathrm{km}$ or inches/mile (Das et al., 1990). In Texas, the IRI values are used by most of the transportation offices as a measure of the state of the surface in order to determine the repair and maintenance strategies (James et al., 1991). The pavement surfaces are considered rough and critical, when the IRI values are higher than a threshold value of $1.5 \mathrm{~m} / \mathrm{km}$. This threshold value has also been adopted by the TxDOT to assess the smoothness of the new and existing pavement sections (Tex-1001-S (TxDOT, 2008)).

Figure 9 shows typical profiler data obtained from the southbound (CQF) and northbound (RAP) carriageways of SH 360. The average IRI values (average of three travel lanes) for both the RAP and CQF sections are summarised in Table 4. The IRI values for the RAP and CQF sections were recorded as between 1.10 and $1.22 \mathrm{~m} / \mathrm{km}$ and between 0.95 and $1.02 \mathrm{~m} / \mathrm{km}$, respectively. Overall, the IRI values of both the sections were less than the threshold value of $1.5 \mathrm{~m} / \mathrm{km}$. Hence, it can be concluded that both the CQF and RAP materials performed adequately as pavement bases to support the pavement structures under high traffic loads for the early monitoring period.

\section{SUSTAINABILITY ASPECTS OF THE PROJECT}

The construction industry requires huge quantities of virgin material and utilisation of these materials has resulted in the depletion of these natural resources. It has been estimated that in the construction of pavements, as much as $12500 \mathrm{t}$ of virgin aggregate is required per kilometre length (Zoorob and 


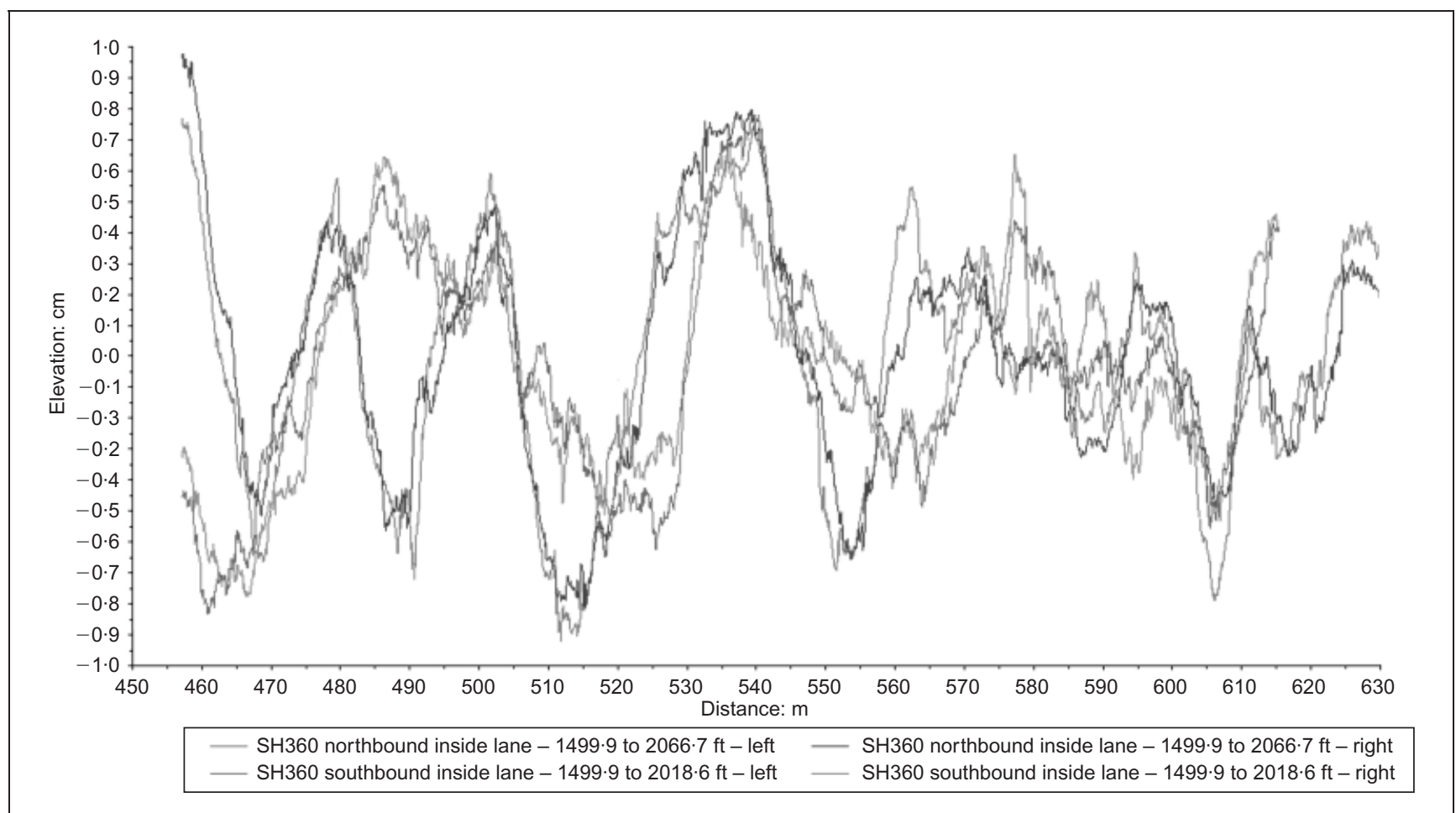

Figure 9. Typical pavement profiler data $(\mathrm{I}$ foot $=0.301 \mathrm{~m})$

\begin{tabular}{|llc|}
\hline Section along SH 360 & \multicolumn{2}{l|}{ Average IRI: $\mathrm{m} / \mathrm{km}$} \\
\cline { 2 - 3 } & Left & Right \\
\hline Northbound lanes (RAP) & 1.10 & 1.22 \\
Southbound lanes (CQF) & 0.95 & 1.02 \\
Table 4. Summary of IRI values $(\mathrm{m} / \mathrm{km}$ ) from RAP and CQF \\
sections
\end{tabular}

Suparma, 2000). This high demand and depletion of natural resources necessitate the investigation of alternative material sources. Several studies have estimated that at least 170 million tons of quarry by-products are generated annually in the United States and 41 million tons in the United Kingdom (Collins and Ciesielski, 1994; Manning, 2004). These numbers are continuously increasing year by year. These studies also reported that only a small fraction of these recycled/secondary materials were being currently used in the construction industry and the rest are stockpiled at quarry sources. Huffman (2001) reported acute problems of stockpiling of QF especially when the quarries are located in metropolitan areas. In the case of reclaimed asphalt pavement materials, although some recycling efforts have been reported, the total utilisation of these materials is still not high due to a lack of awareness of these materials in the prototype environment.

Many researchers have reported that the sustainability aspects of ground improvement projects for pavement construction face difficult questions related to the engineering, socioeconomic and environmental aspects of the construction projects (Ellis, 2003; Horvath, 2003; Harbottle et al., 2008). Fleming et al. (2003) and Lambert et al. (2006) highlighted the need for performance-based specifications of the recycled materials for sustainable pavement design procedures.
This research study addresses some of the above issues by highlighting the engineering/mechanical performance-based characterisation of both recycled/secondary materials to evaluate their potential to serve as pavement bases. As a part of the characterisation, both laboratory and field studies were undertaken as discussed in the previous sections. As noted by Lambert et al. (2006), the shear strength and the resilient behaviour of these recycled/secondary materials are considered to be the most important performance parameters. The laboratory test data showed that these materials behaved in a similar or in some cases superior manner to the conventional base materials.

By using extensive instrumentation the field monitoring data also concluded that these recycled/secondary materials performed adequately under the heavy traffic loads allowed on state highways. The estimated $\mathrm{pH}$ of the leachate was observed to be around $12 \cdot 2$ for both RAP and QF materials, which is similar to the value for lime-treated conventional aggregates. As a result a similar basic environment prevailed at the project sites where these recycled materials were utilised.

Overall, a total of more than $20000 \mathrm{~m}^{3}$ (approximately $40000 \mathrm{t}$ ) of recycled/secondary materials were successfully utilised in the pavement base layers to enhance their structural support, and reduce the roughness on the pavement structure. Furthermore, use of these alternative materials in place of conventional aggregates not only reduced the total cost of the project by approximately 30\% but also showed an approach on how to enhance the use of recycled materials in a large-scale infrastructure application such as pavements. Recycling and reuse of waste materials promote sustainable construction in civil infrastructure since they address various elements of sustainability including engineering, socio-economic and environmental aspects. The 
reuse of these waste materials in base layers has certainly enhanced the involvement of state transportation agencies in promoting sustainability efforts.

\section{SUMMARY AND CONCLUSIONS}

This paper presents the results obtained from both laboratory and field studies on recycled materials such as CQF and RAP to evaluate their roles as pavement base materials for performance-based sustainable pavement design. A series of experiments were carried out to characterise these materials and their engineering behaviour. Field performance studies were also carried out to verify their performance as base materials to support pavement structures. Based on laboratory and field data collected, the following conclusions were drawn.

Both recycled materials were characterised as coarse-grained materials with very low swelling and compressibility values. The untreated QF sample exhibited a considerably lower unconfined compressive strength of $120 \mathrm{kPa}$. However, the strength was improved 12-fold when the QF was treated with 2.3\% cement additive. The high strength of the $\mathrm{CQF}$ is attributed to the cementing reactions between the cement and the fine sandy fraction of the QF material. The UCS value of the RAP was observed to be $340 \mathrm{kPa}$. The measured resilient moduli values of the CQF and RAP were between 300 and $400 \mathrm{MPa}$ and these values were similar to those of coarse aggregates.

Field monitoring of test sections over a period of 2.5 years through the use of horizontal inclinometers installed in the recycled base materials (RAP and CQF) shows that the vertical permanent deformations in both the layers were close to $10 \mathrm{~mm}$. These values were well within the permissible limit of $25 \mathrm{~mm}$. The pressure cells data reveal that the pressures recorded in both the base layers were around $20 \mathrm{kPa}$ which agrees with the expected values under traffic loading on pavement structures. Such low pressure values are likely to reduce the compression-induced settlements in both layers. The IRI values obtained from a profiler run on these pavement test sections showed that the values were around $1 \mathrm{~m} / \mathrm{km}$ and these values were lower than the threshold value of $1.5 \mathrm{~m} / \mathrm{km}$.

From the data obtained during laboratory tests and fieldmonitoring studies and the pavement profiler data, it can be concluded that the recycled materials used in this study performed well to support heavy traffic loads on rigid pavements. Continued monitoring of the test sections is recommended to study the long-term performance of these recycled pavement bases.

Overall, a total of more than $20000 \mathrm{~m}^{3}$ (approximately $40000 \mathrm{t}$ ) of recycled/secondary materials were successfully utilised in pavement base layers to enhance their structural support, and reduce the roughness on the pavement structure. Furthermore, the use of these alternative materials in the place of conventional aggregates has not only reduced the total cost of the project by approximately $30 \%$ but also showed an approach as to how to enhance the use of recycled materials in a large-scale infrastructure application such as pavements. Recycling and reuse of waste materials promote sustainable construction in civil infrastructure since they address various elements of sustainability including engineering, socioeconomic and environmental aspects.

\section{REFERENCES}

Abreu DG, Jefferson I, Braithwaite PA and Chapman DN (2008) Why sustainability is important in geotechnical engineering. In Geo Congress 2008: Geosustainability and Geohazard Mitigation (Khire MV, Reddy KR and Alshawabkeh AN (eds)). American Society for Civil Engineers, Reston, VA, USA, Geotechnical Special Publication 178, pp. 821-828.

Alkins AE, Lane B and Kazmierowski T (2008) Sustainable pavements - environmental, economic, and social benefits of in-situ pavement recycling. Transportation Research Record 2084: 100-103.

AASHTO (American Association of State Highway Transportation Officials) (1993) AASHTO Guide for Design of Pavement Structures. AASHTO, Washington, DC, USA.

AASHTO (2003) AASHTO T 307-99: Standard Method of Test for Determining the Resilient Modulus of Soils and Aggregate Materials. AASHTO, Washington, DC, USA. ASTM (American Society for Testing and Materials) (2004) ASTM D2435: Standard Test Methods for One-Dimensional Consolidation Properties of Soils Using Incremental Loading. ASTM International, West Conshohocken, PA, USA.

ASTM (2005) ASTM D4318: Standard Test Methods for Liquid Limit, Plastic Limit, and Plasticity Index of Soils. ASTM International, West Conshohocken, PA, USA.

ASTM (2006) ASTM D2166: Standard Test Method for Unconfined Compressive Strength of Cohesive Soil. ASTM International, West Conshohocken, PA, USA.

ASTM (2008) ASTM D4546: Standard Test Methods for OneDimensional Swell or Settlement Potential of Cohesive Soils. ASTM International, West Conshohocken, PA, USA.

Chesner WH, Simon MJ and Eighmy TT (2001) Recent federal initiatives for recycled material use in highway construction in the United States. In Beneficial Use of Recycled Materials in Transportation Applications - Arlington Virginia, November 13-15, 2001 (Eighmy TT (ed.)). Air and Waste Management Association, Pittsburgh, PA, USA, pp. 3-10.

Collins RJ and Ciesielski SK (1994) Recycling and use of waste materials and by-products in highway construction. In Synthesis of Highway Practice 199. National Academy Press, Washington, DC, USA, pp. 1-77.

Das SC, Bakeer R, Zhong J and Schutt M (1990) Assessment of Mitigation Embankment Settlement with Pile Supported Approach Slabs. Louisiana Transportation and Research Center, Baton Rouge, LA, USA.

Eades JL and Grim RE (1966) A quick test to determine lime requirements for lime stabilization. Highway Research Record 139: $61-72$.

Ellis SJ (2003) Recycling in transportation. In Transportation Geotechnics (Frost MW, Jefferson I, Faragher E, Roff TEJ and Fleming PR (eds)). Thomas Telford, London, pp. 177-188.

Fleming PR, Rogers CDF, Thom NH and Frost MW (2003) A performance specification for pavement foundations. In Transportation Geotechnics (Frost MW, Jefferson I, Faragher E, Roff TEJ and Fleming PR (eds)). Thomas Telford, London, pp. $161-176$.

Fraser J and McBride RA (2002) The utility of aggregate processing fines in the rehabilitation of dolomite quarries. Land Degradation and Development 11: 1-17.

Harbottle MJ, Tabbaa AA and Evans CW (2008) Sustainability of land remediation. Part I: overall analysis. Proceedings of the Institution of Civil Engineers, Geotechnical Engineering 161(2): 75-92. 
Horvath A (2003) Life-cycle Environmental and Economic Assessment of Using Recycled Materials in Asphalt Pavements. University of California Transportation Center, Berkeley, CA, USA, Technical Report, p. 29.

Huffman M (2001) Limestone pond fines case study: subtitle D landfill soil infiltration layer and other applications. Proceedings ICAR 9th Annual Symposium, Austin TX, USA, p. 15 (CD-ROM).

James RW, Zhang H and Zollinger DG (1991) Observations of severe abutment back wall damage. Transportation Research Record 1319: 55-61.

Janoo VC (1994) Layer Coefficients for NHDOT Pavement Material. Prepared for New Hampshire Department of Transportation and US Department of Transportation, Special Report 94-30.

Jefferis SA (2008) Moving towards sustainability in geotechnical engineering. In Geo Congress 2008: Geosustainability and Geohazard Mitigation (Khire MV, Reddy KR and Alshawabkeh AN (eds)). American Society for Civil Engineers, Reston, VA, USA, Geotechnical Special Publication 178, pp. 844-851.

Jefferson I, Hunt DVL, Birchall CA and Rogers CDF (2007) Sustainability indicators for environmental geotechnics. Proceedings of the Institution of Civil Engineers, Engineering Sustainability 160(2): 57-78.

Kumar DS and Hudson WR (1993) Potential uses for quarry fines. Stone Review 9(2): 12-14.

Lambert P, Fleming PR and Frost MW (2006) Material testing for sustainable pavement foundation design. Proceedings of the Institution of Civil Engineers, Construction Materials 159(4): 139-146.

Lee MT and Nicholson PG (1997) An engineering test program of MSW ash mixed with quarry tailings for use as a construction material. In Testing of Soil Mixed with Waste or Recycled Materials (Wasemiller MA and Hoddinott KB (eds)). American Society for Testing and Materials, West Conshohocken, PA, USA, ASTM STP 1275, pp. 205-218.

Manning D (2004) Exploration and use of quarry fines. In Mineral Solutions. Manchester Institute of Science and Technology, Manchester, Report No. 087/MIST2/DACM/01, MIST project reference: MA/2/4/003.

Naik TR and Kumar R (2003) Use of Limestone Quarry Byproducts for Developing Economical Self-compacting Concrete. UWM Center for By-Products Utilization, University of Wisconsin - Milwaukee, WI, USA, Report No. CBU-2003-15.

NOAA (National Oceanic and Atmospheric Administration) (2008) See http://www.ncdc.noaa.gov/oa/ncdc.html (accessed 10/10/2008).

Nunes M, Bridges M and Dawson A (1996) Assessment of secondary materials for pavement construction: Technical and environmental aspects. Waste Management 16(1-3): 87-96.

Okamura H (1997) Self-compacting high performance concrete. ACI Concrete International 19(7): 50-54.
Puppala AJ, Griffin JA, Hoyos LR and Chomtid S (2004) Studies on sulfate-resistant cement stabilization methods to address sulfate-induced soil heave. Journal of Geotechnical and Geoenvironmental Engineering, ASCE 130(4): 391-402.

Puppala AJ, Saride S, Potturi A and Hoyos LR (2009) Resilient behavior of cement-fiber treated reclaimed asphalt pavement (rap) aggregates as bases. In Contemporary Topics in Ground Modification, Problem Soils, and Geo-Support (Hussein MH, Iskander MG and Laefer DF (eds)). American Society for Civil Engineers, Reston, VA, USA, Geotechnical Special Publication 187, pp. 433-440.

Reid MJ and Chandler JWE (2001) Recycling in Transportation Infrastructure. TRL Limited, Crowthorne.

Sirivitmaitrie C (2008) Novel Stabilization Methods for Sulfate and Non-sulfate Soils. PhD thesis, The University of Texas at Arlington, $294 \mathrm{pp}$.

Soosan TG, Jose BT and Abraham BM (2001) Use of quarry dust in embankment and highway construction. In Proceedings of Indian Geo-Technical Conference, Indore. New Phoenix, New Delhi, India, pp. 274-277.

Taha R, Ali G, Basma A and Al-Turk 0 (1999) Evaluation of reclaimed asphalt pavement aggregate in road bases and sub bases. In Proceedings of 7th International Conference on Low-volume Roads. Transportation Research Board, National Research Council, Washington, DC, USA, pp. 264-269 and Transportation Research Record 1652: 1.

Taha R, Ali A, Khalid A and Muamer A (2002) Cement stabilization of reclaimed asphalt pavement aggregates for road bases and subbases. Journal of Materials in Civil Engineering 14(3): 239-245.

Tao M, Zhang Z and Wu Z (2008) Simple procedure to assess performance and cost benefits of using recycled materials in pavement construction. Journal of Materials in Civil Engineering, ASCE 20(11): 718-725.

Tarun RN, Rudolph NK, Chun YM, Fethullah C and Bruce WR (2005) Use of fly ash and limestone quarry by-products for developing economical self-compacting concrete. Proceedings of the International Congress on Fly Ash Utilization, New Delhi, India, 4-7 December.

Tepordei VV (1992) Construction Sand and Gravel. Annual Report 1990. US Department of Interior, Bureau of Mines, Washington, DC, USA.

TxDOT (Texas Department of Transportation) (1999) Tex124-E: Test Procedure for Determining Potential Vertical Rise. TxD0T, Austin, TX, USA, Designation: Tex-124-E, p. 11.

TxD0T (2008) Tex-1001-S: Test Procedure for Operating Internal Profilers and Evaluating Pavement Profiles. TxDOT, Austin, TX, USA, Designation: Tex-1001-S. p. 17.

Zoorob SE and Suparma LB (2000) Laboratory design and investigation of the properties of continuously graded asphaltic concrete containing recycled plastics aggregate replacement (Plastiphalt). Cement and Concrete Composites 22(2): $233-242$.

\section{What do you think?}

To discuss this paper, please email up to 500 words to the editor at journals@ice.org.uk. Your contribution will be forwarded to the author(s) for a reply and, if considered appropriate by the editorial panel, will be published as discussion in a future issue of the journal.

Proceedings journals rely entirely on contributions sent in by civil engineering professionals, academics and students. Papers should be 2000-5000 words long (briefing papers should be 1000-2000 words long), with adequate illustrations and references. You can submit your paper online via www.icevirtuallibrary.com/content/journals, where you will also find detailed author guidelines. 